\title{
PERBEDAAN ANTARA KOMBINASI MASSAGE WOOLWICH DAN MASSAGE ROLLING DENGAN TEKNIK MARMET TERHADAP PRODUKSI ASI PADA IBU NIFAS DI WILAYAH KERJA PUSKESMAS KARANG PULE
}

\author{
Juninda Nurfija ${ }^{1}$, Ni Nengah Arini Murni² \\ ${ }^{1}$ Jurusan Kebidanan Poltekkes Kemenkes Mataram \\ ${ }^{2}$ Jurusan Kebidanan Poltekkes Kemenkes Mataram
}

\begin{abstract}
Abstrak
ASI eksklusif merupakan salah satu program yang cukup sulit dikembangkan karena berkaitan dengan berbagai permasalahan sosial di masyarakat. Untuk mencegah dan menangani masalah laktasi tersebut, maka dimungkinkan sebuah intervensi yaitu Kombinasi Masssage Woolwich dan Massage Rolling serta Tekhnik Marmet. Dilakukannya penelitian ini yaitu guna mengetahui adanya perbedaan Kombinasi Masssage Woolwich dan Massage Rolling dengan Tekhnik Marmet terhadap produksi ASI ibu nifas di wilayah kerja Puskesmas Karang Pule. Penelitian ini menggunakan rancangan penelitian Quasi Eksperiment dengan menggunakan rancangan post test only design with control group. Populasi penelitian ini adalah seluruh ibu nifas di wilayah kerja Puskesmas Karang Pule, sampel diambil dengan consecutive sampling dengan jumlah 34 orang. Analisis data menggunakan Independent T- test untuk mengetahui adanya perbedaan produksi ASI antara dua kelompok intervensi. Produksi ASI pada kelompok intervensi kombinasi massage woolwich dan massage rolling didapatkan rata-rata yaitu 29,12 cc. Sementara produksi ASI pada kelompok dengan tehnik marmet didapatkan rata-rata yaitu 22,35 cc. Uji statistik yang digunakan adalah Independent T-test didapatkan hasil nilai t sebesar 2,617 dan signifikansi $(p) 0,013<0,05$. Ada Perbedaan antara kombinasi massage woolwich dan massage rolling dengan tekhnik marmet terhadap produksi ASI ibu nifas di wilayah kerja Puskesmas Karang Pule Tahun 2019.
\end{abstract}

Kata Kunci : Massage Woolwich ; Tekhnik Marmet ; Produksi ASI

\section{THE DIFFERENT BETWEEN THE COMBINATION OF WOOLWICH MASSAGE AND ROLLING MASSAGE WITH MARMET TECHNIQUE TO MILK PRODUCTION OF POSTPARTUM MOTHER IN THE WORKING AREA OF PUSKESMAS KARANG PULE IN YEAR 2019}

\begin{abstract}
Exclusive breastfeeding is one program that is quite difficult to develop because it is related to various social problems in the community. To prevent and deal with the problem of lactation, an intervention is possible, namely a combination of wolwich massage, Rolling Massage and Marmet Technique. This research is conducted to find the different of woolwich massage
\end{abstract}


combination and rolling massage with marmet technique to milk production of postpartum mother in the working area of Karang Pule Public Health Center in 2019. This study used a Quasi Experiment design using a post test only design with control group. The population was all postpartum mothers at working area of Karang Pule Public Health Center, samples were taken with consecutive sampling with a total of 34 people. Data analysis used the Independent Ttest to determine the differences in ASI production between the two intervention groups. Breast milk production in the intervention group combined of woolwich massage and rolling massage obtained an average of $29.12 \mathrm{cc}$. While breast milk production in the group with the marmet technique was obtained an average of $22.35 \mathrm{cc}$. The statistical test used is the Independent T-test, the results of the $t$ value are 2.617 and the significance $(p)$ is $0.013<0.05$. There is a difference between the combination of massage woolwich and rolling massage with marmet techniques on the production of breast milk for postpartum mothers in the work area of the Karang Pule Health Center in 2019.

Keywords: Woolwich Massage ; Marmet Technique ; Breast Milk Production

\section{Pendahuluan}

Organisasi Kesehatan Dunia (WHO) merekomendasikan agar setiap bayi baru lahir mendapatkan ASI eksklusif selama enam bulan. Pemberian ASI eksklusif selama enam bulan sudah dibuktikan secara ilmiah dapat memenuhi kebutuhan nutrisi bayi (Roesli, 2008). Namun, ASI eksklusif merupakan salah satu program yang cukup sulit dikembangkan karena berkaitan dengan berbagai permasalahan sosial di masyarakat. Pada tahun 2017 cakupan ASI eksklusif di provinsi NTB sebesar 77,66\%, cakupan ini menurun jika dibandingkan dengan cakupan ASI Ekslusif tahun 2016 sebesar 86,63\%. Lebih rinci, cakupan ASI eksklusif di Kota Mataram pada tahun 2017 sebesar 75,48\%, cakupan ini juga menurun jika dibandingkan dengan cakupan 2016 sebesar 79,90\%. ${ }^{3}$

Salah satu alasan penyebab ketidak berhasilan pemberian ASI eksklusif ini adalah ibu kurang percaya diri bahwa ASI yang dimiliki dapat mencukupi kebutuhan nutrisi bayinya. ${ }^{15}$ Hal ini terjadi karena ASI yang tidak keluar atau hanya keluar sedikit pada hari-hari pertama setelah melahirkan. Menurut Riset Kesehatan Dasar (2013), proses mulai menyusu terbanyak terjadi pada 1-6 jam setelah kelahiran $(35,2 \%)$ dan kurang dari 1 jam IMD (inisiasi menyusu dini) sebesar 34,5\%, sedangkan mulai proses menyusu terendah terjadi pada 7-23 jam setelah kelahiranya itu sebesar 3,7\% (Kemenkes RI, 2015. Menyusu dini merupakan kunci awal dari suksesnya praktek menyusui, dimana ASI diberikan segera dalam waktu 3 menit setelah lahir. produksi ASI dan ejeksi ASI yang sedikit pada hari hari pertama setelah melahirkan menjadi kendala dalam pemberian ASI secara dini. ${ }^{14}$

Pemberian nutrisi yang optimal sejak dini dapat diberikan melalui pemberian air susu ibu (ASI) secara eksklusif bagi bayi baru lahir. Air susu ibu (ASI) adalah cairan khusus yang kompleks, unik dan dihasilkan oleh kedua kelenjar payudara. ASI merupakan cairan yang terbaik bagi bayi baru lahir sampai usia 6 bulan karena komponen ASI mudah di cerna, mudah diabsorbsi oleh bayi baru lahir, dan memiliki 
kandungan nutrient terbaik dibandingkan dengan susu formula. ${ }^{10}$

Jumlah ibu menyusui $42 \%$ namun, hanya $44 \%$ yang berhasil laktasi pada 1 jam pertama setelah lahir dan hanya $62 \%$ dalam hari pertama setelah lahir serta 5,8\% dalam satu bulan pertama. Laktasi dini atau pemberian ASI awal pada jam pertama setelah lahir akan merangsang terjadinya peningkatan prolaktin dalam darah dan mencapai puncak pada 45 menit pertama apabila ASI dikeluarkan atau dikosongkan secara menyeluruh maka akan meningkatkan produksi ASI menjadi lebih banyak. Pemberian ASI awal dapat mempengaruhi pemberian ASI pada bayi sampai usia 6 bulan. ${ }^{16}$ Dalam kondisi yang penuh kehawatiran dan tidak percaya diri karena merasa ASInya tidak cukup , ibu memerlukan bantuan dan dukungan untuk dapat mempertahankan produksi ASI. Dengan rasa tidak percaya diri dan kehawatiran akan menyebabkan terhambatnya pengeluaran hormon oksitosin. Hormon oksitosin berdampak pada pengeluaran hormone prolaktin sebagai stimulasi produksi ASI pada ibu selama menyusui. ${ }^{1}$

Menyikapi permasalahan laktasi tersebut, pemerintah Indonesia telah menggalakkan program laktasi melalui Manajemen Laktasi yang merupakan salah satu program dari Kesehatan Ibu dan Anak (KIA). Manajemen 4 laktasi adalah suatu tatalaksana menyeluruh yang menyangkut laktasi dan penggunaan ASI, menuju suatu keberhasilan menyusui untuk memelihara kesehatan ibu dan bayinya. Disamping itu, untuk meningkatkan cakupan ASI Eksklusif dengan ditetapkan PeraturanPemerintah (PP) No 33/2012 tentang Pemberian ASI Eksklusif sebagai jaminan pemenuhan hak bayi untuk mendapatkan sumber makanan terbaik (ASI) sejak dilahirkan sampai berusia enam bulan tanpa menambah dan/atau mengganti dengan makanan atau minuman lain, melindungi ibu dalam memberikan ASI eksklusif kepada bayi, program Inisiasi Menyusu Dini (IMD), pengaturan penggunaan susu formula dan produk bayi lainnya, serta sarana menyusui di tempat kerja dan sarana umum lainnya. ${ }^{7,14}$

Mencegah dan menangani masalah laktasi tersebut, maka dimungkinkan sebuah intervensi yaitu metode pijat woolwich, metode pijat ini didasarkan pada pengamatan bahwa pengaliran ASI lebih penting dari sekresi ASI oleh kelenjar ASI. Pemijatan dilakukan pada area sinus laktiferus tepatnya 1-1,5 cm diatas areola mamae, dengan tujuan mengeluarkan ASI yang ada pada sinus laktiferus. ${ }^{10}$

Pemijatan tersebut akan merangsang sel darah pada payudara,rangsangan tersebut diteruskan ke hipotalamus dan direspon oleh hipofisis anterior untuk mengeluarkan hormone prolaktin yang akan dialirkan oleh darah ke sel mioepitel payudara untuk memroduksi ASI. Manfaat pemijatan metode woolwich adalah meningkatkan sekresi ASI dan mencegah peradangan payudara atau mastitis. ${ }^{10}$ Sedangkan Metode massage rolling (punggung) mempercepat syaraf parasimpatis menyampaikan sinyal ke otak bagian belakang untuk merangsang kerja oksitosin dalam mengalirkan ASI agar keluar. ${ }^{15}$

Berdasarkan uraian di atas perlu dilakukan penelitian tentang perbedaan antara kombinasi massage woolwich dan massage rolling dengan tekhnik marmet terhadap produksi asi ibu nifas di wilayah kerja puskesmas karang pule tahun 2019. 


\section{Metode Penelitian}

Desain penelitian ini merupakan penelitian eksperimental dengan jenis eksperimental quasi (semu). Penelitian eksperimental adalah suatu prosedur penelitian yang dilakukan dengan memberikan perlakuan/ intervensi pada subjek penelitian, dengan tujuan menilai pengaruh suatu perlakuan pada variabel independen terhadap variabel dependen.

Dalam penelitian ini kelompok kontrol diberikan perlakukan, yaitu ibu nifas dilakukan stimulasi dengan menggunakan Metode Teknik Marmet sehingga dapat melihat perbedaan produksi ASI dengan menggunakan beberapa tekhnik.

Rancangan yang digunakan adalah post test only design with control group yaitu suatu pengukutan hanya dilakukan pada saat terakhir penelitian. Dalam rancangan ini intervensi dilakukan pada kedua kelompok dengan pemberian intervensi yang berbeda yaitu "kombinasi massage woolwich dan massage rolling dan tekhnik marmet", mulai hari 1 sampai hari ke 3 masa nifas.

\section{Hasil dan Pembahasan}

1. Karakteristik Responden

Distribusi frekuensi karakteristik ibu nifas meliputi umur ibu, pendidikan, pekerjaan, dan paritas saat awal kontak di wilayah kerja Puskesmas Karang pule tahun 2019 yang mana dapat di lihat pada tabel 1 di bawah ini.

a. Umur

Distribusi frekuensi umur ibu nifas di wilayah kerja Puskesmas Karang Pule dapat dilihat pada tabel berikut:

Tabel 1. Distribusi Umur Ibu Nifas di Wilayah Kerja Puskesmas Karang Pule Tahun 2019.

\begin{tabular}{|c|c|c|c|c|c|}
\hline \multirow[t]{2}{*}{ No } & \multirow{2}{*}{ Umur } & \multicolumn{2}{|c|}{$\begin{array}{c}\text { Kombinasi } \\
\text { Woolwich dan Rolling }\end{array}$} & \multicolumn{2}{|c|}{ Tekhnik Marmet } \\
\hline & & $(n=17)$ & $\%$ & $(n=17)$ & $\%$ \\
\hline 1. & $<20$ tahun & 2 & 11, & 1 & 5,9 \\
\hline 2. & 20-35 tahun & 14 & 82 & 14 & 82,4 \\
\hline 3. & $>35$ tahun & 1 & 5,9 & 2 & 11,8 \\
\hline
\end{tabular}

Berdasarkan tabel di atas maka didapatkan hasil frekuensi umur tertinggi pada kelompok kombinasi massage woolwich dan massage rolling yaitu umur 20-35 tahun sebanyak 14 orang $(82,4 \%)$ dan terendah umur $>35$ tahun sebanyak 1 orang $(5,9 \%)$, sedangkan frekuensi umur tertinggi pada kelompok tekhnik marmet adalah $20-35$ tahun sebanyak 14 orang $(82,4 \%)$ dan terendah umur $<20$ tahun sebanyak 1 orang $(5,9 \%)$. 
b. Pendidikan

Distribusi frekuensi pendidikan ibu nifas di wilayah kerja Puskesmas Karang Pule dapat dilihat pada tabel berikut:

Tabel 2. Distribusi Pendedikan Ibu Nifas di Wilayah Kerja Puskesmas Karang Pule Tahun 2019.

\begin{tabular}{llcccc}
\hline \multirow{2}{*}{ No } & \multirow{2}{*}{ pendidikan } & \multicolumn{2}{c}{$\begin{array}{c}\text { Kombinasi Woolwich } \\
\text { Dan Rolling }\end{array}$} & \multicolumn{2}{c}{ Tekhnik Marmet } \\
\cline { 3 - 6 } & & 1 & 5,9 & 0 & 0,0 \\
\hline 1. & Tidak Sekolah & 2 & 11,8, & 2 & 11,8 \\
\hline 2. & SD & 5 & 29,4 & 5 & 29,4 \\
\hline 3. & SMP & 8 & 47,0 & 9 & 52,9 \\
\hline 4. & SMA & 1 & 5,9 & 1 & 5,9 \\
\hline 5. & Perguruan Tinggi & & & & \\
\hline
\end{tabular}

Berdasarkan tabel di atas tingkat pendidikan tertinggi pada kelompok kombinasi massage woolwich dan massage rolling yakni SMA sebanyak 8 orang (47\%) dan tingkat pendidikan terendah yakni Tidak Sekolah sebanyak 1 orang $(5,9 \%)$, sedangkan pendidikan tertinggi pada kelompok tekhnik marmet yaitu SMA sebanyak 19 orang $(52,9 \%)$ dan pendidikan terendah yakni Perguruan Tinggi sebanyak 1 orang $(5,9 \%)$.

c. Pekerjaan

Distribusi frekuensi pekerjaan ibu nifas di wilayah kerja Puskesmas Karang Pule dapat dilihat pada tabel berikut:

Tabel 3. Distribusi Pendidikan Ibu Nifas di Wilayah Kerja Puskesmas Karang Pule Tahun 2019.

\begin{tabular}{cccccc}
\hline \multirow{2}{*}{ No } & \multirow{2}{*}{ Pekerjaan } & \multicolumn{2}{c}{$\begin{array}{c}\text { Kombinasi Woolwich } \\
\text { dan Rolling }\end{array}$} & \multicolumn{2}{c}{ Tekhnik Marmet } \\
\cline { 3 - 6 } & & $\mathbf{( n = 1 7 )}$ & $\mathbf{\%}$ & $\mathbf{( n = 1 7 )}$ & $\mathbf{\%}$ \\
\hline 1 & Bekerja & 5 & 29,4 & 5 & 29,4 \\
\hline 2 & Tidak Bekerja & 12 & 70,6 & 12 & 70,6 \\
\hline
\end{tabular}

Sebagian besar pada kelompok kombinasi massage woolwich dan massage rolling tidak bekerja sebanyak 12 orang $(70,6 \%)$ dan yang tidak bekerja sebanyak 5 orang $(29,4 \%)$, begitu juga dengan kelompok tekhnik marmet ibu yang tidak bekerja sebanyak 12 orang $(70,6 \%)$ dan yang tidak bekerja sebanyak 5 orang $(29,4 \%)$.

d. Paritas

Distribusi frekuensi paritas ibu nifas di wilayah kerja Puskesmas Karang Pule dapat dilihat pada tabel berikut: 
Tabel 4. Distribusi Paritas Ibu Nifas di Wilayah Kerja Puskesmas Karang Pule Tahun 2019

\begin{tabular}{lcccc}
\hline \multirow{2}{*}{ Pekerjaan } & \multicolumn{2}{c}{$\begin{array}{c}\text { Kombinasi Woolwich } \\
\text { dan Rolling }\end{array}$} & \multicolumn{2}{c}{ Tekhnik Marmet } \\
\cline { 2 - 5 } & $\mathbf{( n = 1 7 )}$ & $\mathbf{\%}$ & $\mathbf{( n = 1 7 )}$ & $\mathbf{\%}$ \\
\hline Primigravida & 4 & 23,5 & 1 & 5,9 \\
\hline Multigravida & 13 & 76,5 & 16 & 94,1 \\
\hline
\end{tabular}


Rata-rata ibu nifas pada kelompok kombinasi massage woolwich dan massage rolling memiliki jumlah kehamilan multigravida yakni sebanyak 13 orang (76,5\%) dan sisanya sebanyak 4 orang $(23,5 \%)$ hamil primigravida, sedangkan pada kelompok tekhnik marmet ibu nifas dengan multigravida sebanyak 16 orang $(94,1 \%)$ dan sisanya sebanyak 1 orang $(5,9 \%)$ dengan primigravida.

2. Produksi Asi Ibu Nifas Setelah Diberikan Intervensi Dengan Kombinasi Massage Woolwich Dan Massage Rolling Serta Tekhnik Marmet.

Ibu nifas telah diberikan intervensi dengan kombinasi massage woolwich dan masage rolling dan juga tekhnik marmet di hari pertama sampai hari ketiga. Kemudian dilakukan evaluasi dihari keempat masa nifas. Berikut merupakan hasil evaluasi produksi ASI ibu nifas dalam satuan cc, yang dapat dilihat pada tabel di bawah ini:

Tabel 5. Produksi Asi Ibu Nifas Setelah Diberikan Intervensi Dengan Kombinasi Massage Woolwich Dan Massage Rolling Serta Tekhnik Marmet di Wilayah Kerja Puskesmas Karang Pule Tahun 2019.

\begin{tabular}{|c|c|c|c|}
\hline \multirow{2}{*}{ No } & \multirow{2}{*}{$\begin{array}{l}\text { Produksi ASI } \\
4 \text { hari PP (cc) }\end{array}$} & \multicolumn{2}{|c|}{ Kelompok Intervensi } \\
\hline & & $\begin{array}{l}\text { Kombinasi Woolwich } \\
\text { Dan Rolling } \\
(n=17)\end{array}$ & $\begin{array}{l}\text { Tekhnik Marmet } \\
\qquad(\mathrm{n}=17)\end{array}$ \\
\hline 1 & Minimal & 15 & 15 \\
\hline 2 & Maksimal & 45 & 35 \\
\hline 3 & Mean & 29,12 & 22,35 \\
\hline 4 & SD & 8,880 & 5,894 \\
\hline
\end{tabular}

Berdasarkan tabel di atas, pada kelompok Kombinasi Massage Woolwich Dan Massage Rolling didapatkan sebanyak $17 \mathrm{ibu}$ nifas, hasil analisis didapatkan rata-rata produksi ASI setelah adalah 29,12 cc, dengan nilai standar deviasi 8,88, produksi ASI tertinggi sebanyak $45 \mathrm{cc}$, dan produksi ASI terendah sebanyak $15 \mathrm{cc}$. Sedangkan hasil analisis $17 \mathrm{ibu}$ nifas pada kelompok yang diberikan intervensi dengan Tekhnik Marmet didapatkan rata-rata produksi ASI sebanyak 22,35 cc, dengan nilai standar deviasi 5,894, produksi ASI tertinggi sebanyak $35 \mathrm{cc}$, dan produksi ASI terendah sebanyak $15 \mathrm{cc}$.

3. Perbedaan Anatara Kombinasi Massage Woolwich Dan Massage Rolling Dengan Tekhnik Marmet Terhadap Produksi ASI Ibu Nifas Di Wilayah Kerja Puskesmas Karang Pule.

Gambaran analisis uji statistika pada Perbedaan Kombinasi Massage Woolwich Dan 
Massage Rolling Dengan Tekhnik Marmet Terhadap Produksi ASI Ibu Nifas Di Wilayah Kerja Puskesmas Karang Pule Tahun 2019. Berikut penyajian data dalam bentuk tabel :

\begin{tabular}{|c|c|c|c|c|}
\hline \multirow{2}{*}{ No } & \multirow{2}{*}{$\begin{array}{l}\text { Produksi ASI } \\
4 \text { hari PP (cc) }\end{array}$} & \multicolumn{2}{|c|}{$\begin{array}{l}\text { Kelompok } \\
\text { Intervensi }\end{array}$} & \multirow[t]{2}{*}{ p Value } \\
\hline & & $\begin{array}{c}\text { Kombinasi } \\
\text { Woolwich Dan } \\
\text { Rolling } \\
(\mathbf{n}=\mathbf{1 7}) \\
\end{array}$ & $\begin{array}{c}\text { Tekhni k } \\
\text { Marmet } \\
(n=17)\end{array}$ & \\
\hline 1 & Minimal & 15 & 15 & \multirow{4}{*}{0,013} \\
\hline 2 & Maksimal & 45 & 35 & \\
\hline 3 & Mean & 29,12 & 22,35 & \\
\hline 4 & SD & 8,880 & 5,894 & \\
\hline
\end{tabular}

Berdasarkan tabel di atas hasil perhitungan dengan uji independent t- Test pada simtem komputerisasi dengan SPSS 20.0 didapatkan $p$ value $<0,05$ maka kesimpulannya ada perbedaan antara kombinasi massage woolwich dan massage rolling dengan tekhnik marmet terhadap produksi asi ibu nifas. Dari output didapatkan nilai $(p)=0,013<\alpha=0,05$. Karena $p<\alpha$, maka H0 ditolak dan Ha diterima. Sehingga kesimpulan yang didapat adalah ada perbedaan antara Kombinasi Massage Woolwich Dan Massage Rolling Dengan Tekhnik Marmet.

Rata-rata produksi ASI pada kelompok intervensi kombinasi massage woolwich dan massage rolling adalah 29,12 cc, produksi ASI tertinggi sebanyak 45 cc, dan produksi ASI terendah sebanyak 15 cc. Sedangkan hasil analisis 17 ibu nifas pada kelompok yang diberikan intervensi dengan Tekhnik Marmet didapatkan ratarata produksi ASI sebanyak 22,35 cc, dengan nilai standar deviasi 5,894, produksi ASI tertinggi sebanyak $35 \mathrm{cc}$, dan produksi ASI terendah sebanyak $15 \mathrm{cc}$. Pada hari ketiga ukuran lambung bayi membesar menjadi seukuran bola bekel atau seukuran kepalan tangannya. Sehingga sekali menyusui lambung bisa menampung 22-27 cc (Mufdlilah, 2017). Sesuai dengan rata- rata yang didapatkan pada penelitian ini, 5 menit pertama didapatkan rata- rata sebesar 22,35 cc dan 29,12 cc. Jadi, dapat disimpulkan pada penelitian ini ibu nifas yang diberikan intervensi memiliki produksi ASI yang cukup dan sesuai dengan kebutuhan bayinya.

Dari hasil analisis yang dilakukan dengan Independent T-test diperoleh hasil bahwa $\mathrm{H} 0$ ditolak dan $\mathrm{Ha}_{\mathrm{a}}$ diterima dengan taraf signifikan (p) sebesar 0,013 $(p<0,05)$. Hal ini menunjukkan bahwa ada perbedaan kombinasi massage woolwich 
dan massage rolling dengan tekhnik marmet terhadap produksi asi ibu nifas. Dari hasil tersebut menyatakan bahwa berhasilnya kedua tekhnik (kombinasi massage woolwich dan massage rolling, tekhnik marmet) yang diberikan terhadap produksi ASI ibu nifas.

Setelah dilakukan perbandingan hasil rata-rata produki ASI antara kelompok intervensi didapatkan pada kelompok kombinasi 29.12 cc sedangkan kelompok tekhnik marmet 22,35 cc. Jadi dapat disimpulkan ibu nifas yang diberikan kombinasi massage woolwich dan massage rolling memiliki rata-rata jumlah ASI lebih banyak. Keterlambatan pengeluaran produksi ASI pada kelompok tekhnik marmet disebabkan ibu nifas hanya di massase di bagian payudara, sementara massage punggung tidak diberikan.

Seperti penelitian yang dilakukan oleh Pamuji, Supriyana, Sri, et al. (2014) dengan judul "pengaruh kombinasi metode pijat woolwich dan endorphine terhadap kadar hormon prolaktin dan volume ASI (studi pada ibu postpartum di griya hamil sehat Mejasem Kabupaten Tegal) bahwa woolwich massage dapat menstimulus pengeluaran ASI dengan hasil volume ASI pada kelompok intervensi pra dan pasca tindakan terdapat perbedaan, dimana $\mathrm{p}$ value $0,005<\alpha(0,05)$. Sedangkan teknik memerah ASI dengan cara marmet ini pada prinsipnya bertujuan untuk mengosongkan ASI pada sinus laktiferus yang terletak di bawah areola sehingga diharapkan dengan mengosongkan ASI pada daerah sinus laktiferus ini akan merangsang pengeluaran hormon prolaktin. Pengeluaran hormon prolaktin ini selanjutnya akan merangsang mammary alveoli untuk memproduksi ASI. Makin banyak ASI dikeluarkan atau dikosongkan dari payudara maka semakin banyak ASI diproduksi. ${ }^{15,20}$

Ada beberapa penelitian yang terkait dengan penelitian ini sebagai berikut: Hasil penelitian Desmawati (2013), dijelaskan bahwa dengan memberikan masase pada areola mamae sejak dini sangat bermanfaat untuk membantu proses pengeluaran ASI. Pada postpartum yang diberikan intervensi 12 jam setelah bersalin, ASI keluar pada 18 jam setelah bersalin. Masase pada areol mamae merangsang pengeluaran oksitosin sehingga memperlancar proses pengeluaran ASI. Becker (2015) melakukan penelitian di unit neonatal, penelitian ini menjelaskan 
bahwa untuk menghasilkan volume air susu yang lebih banyak, ibu yang akan menyusui harus berada dalam kondisi rileks secara psikologis. Selain itu, dapat juga dilakukan pemijatan sambil dilakukan pengosongan atau pemompaan. Dengan memperhatikan teknik-teknik ini, proses menyusui menjadi lebih efektif. ${ }^{17}$

\section{Kesimpulan}

1. Produksi ASI ibu nifas yang diberikan intervensi dengan kombinasi massage woolwich dan massage rolling setelah dipompa 5 menit didapatkan rata-rata sebanyak 29,12 cc, sedangkan produksi ASI ibu nifas yang diberikan intervensi dengan teknik marmet didapatkan rata- rata sebanyak $22,35 \mathrm{cc}$.

2. Ada perbedaan antara kombinasi massage woolwich dan massage rolling dengan teknik marmet terhadap produksi ASI ibu nifas.

\section{Daftar Pustaka}

1. Amin, et.al . 2011. Efektifitas Massase Rolling (Punggung) terhadap Produksi ASI pada Ibu Post Operasi Sectio Caesarea di RS Muhammadiyah Palembang. http://poltekkespalembang.ac.id/userfil es/files/efektifitas_massase_rolling_\% 28punggung\%29.pdf. Diakses pada tanggal 12 Februari 2019.

2. Depkes RI. 2008. Perawatan Bayi Berat Lahir Rendah (BBLR) dengan Metode Kanguru. Jakarta: Health Technology Assessment Indonesia. Depkes RI.

3. Dinas Kesehatan Provinsi NTB. 2017. Profil Dinas Kesehatan Tahun 2017.

4. Hastono Priyo, S. 2007. Analisis Data. Jakarta: Fakultas Kesehatan Masyarakat Universitas Indonesia.

5. Haryono dan Setianingsih, S. 2014. Manfaat Asi Eksklusif Untuk Buah Hati Anda. Yogyakarta: Gosyen Publising.

6. Hidayat, Aziz Alimul, 2008. Metode Penelitian Keperawatan dan Teknik Analisis. Jakarta: Yayasan Bina Pustaka.

7. Kementerian Kesehatan RI. 2015. Profil Kesehatan Indonesia Tahun 2015 Notoatmodjo, S. 2010. Metodologi Penelitian

8. Kesehatan. Jakarta: PT Rineka Cipta Notoatmodjo, soekidjo. 2012. Metodologi

9. Penelitian Kesehatan. Jakarta: Rineka Cipta.

10. Pamuji. 2014. Pengaruh Kombinasi Metode Pijat Woolwich dan Endorphine Terhadap Kadar Hormon Prolaktin dan Volume ASI (Studi Pada Ibu Postpartum Di Griya Hamil Sehat Mejasem Kabupaten Tegal). Vol. 5. No. 1. BHAMADA, JITK,. Perry, E.,

11. Shanon., Hockenberry, J.M., Lowdermilk,L.D.,Wilson.D.,(2010).

12. Rahardjo, Susilo \& Gudnanto. 2011. Pemahaman Individu Teknik Non Tes. Kudus: 
Nora Media Enterprise Riduan.

13. 2006. Skala Pengukuran Variabel Penelitian. Bandung Alfabeta

14. Riskesdas. 2013. Rencana Kerja Pembinaan Gizi Masyarakat Tahun 2013. Jakarta: Direktorat Bina Gizi Kemenkes RI

15. Roesli, U. 2008. Inisiasi Menyusu Dini Plus ASI Eksklusif. Jakarta : Pustaka

16. SDKI. 2012. Kesejahteraan Ibu dan Anak. Jakarta: SDKI.

17. Sudarti. Fauziah, Afroh. 2013. Asuhan Kebidanan Neonatus Bayi dan Balita. Yogyakarta : Nuha Medika

18. Sugiyono. 2010. Metode Penelitian Kuantitatif, Kualitatif, dan R\&D. Bandung: Alfabeta.

19. Sugiyono. 2012. Metode Penelitian Kesehatan, Bandung: Alfabeta.

20. Suman RAO P N, dkk. 2008. Kangaroo Mother Care for Low Birth Weight Infants: A Randomized Controlled Trial : Indian Pediatrics Volume 45. 